\title{
New Concept Note on Affordable Efficient Energy Utilization with Right Selection of Reliable Solar Converters for Household Loads
}

\author{
Richa Parmar ${ }^{1 *}$, Chandan Banerjee ${ }^{1}$, Ganesh Gowri ${ }^{2}$ \\ ${ }^{1}$ National Institute of Solar Energy, Gwal Pahari, Gurugram, Haryana, India \\ ${ }^{2}$ Mitsui Chemicals India Private Limited, Gujarat, India
}

\begin{abstract}
This paper presents a detailed description of three methodologies to electrify the rural households of small loads with reliable and economical method using solar energy as input source of power. It is observed that high DC voltage is better and economical solution rather than AC based solar systems and low voltage DC systems. In this paper, three methodologies were analysed to select the right combination of portable converters with low prices, which may further enhance the energy access and affordability to common people. The proposed three methodologies were tested through action research in collaboration with a team of scientists and technical experts of National Institute of Solar Energy. The comparative analysis is carried out on three different converters, various kind of house loads and types of power supply i.e. AC/DC. The performance, quality and economic evaluation has been carried out with the help of MATLAB SIMULINK and other measuring instruments specific for solar photovoltaic systems. The derived results were analysed and inferences made for use in village household loads and their income groups. Further, a three-step analytical framework on village-level power energy efficient power at affordable power preposition was presented. This study will help in the designing as well as in the performance and economic evaluation of converters based on solar photovoltaic systems of different technologies.
\end{abstract}

Keywords: DC-DC Converter, DC-AC Converter, Solar Photovoltaic, Efficiency, Cost Analysis.

\footnotetext{
* Corresponding Author E-mail: richa.parmar@nise.res.in
}

Ph: +91-0124-285-3127 


\begin{tabular}{|c|c|}
\hline \multicolumn{2}{|r|}{ Nomenclature } \\
\hline SPV & Solar Photovoltaic \\
\hline PV & Photovoltaic \\
\hline MPPT & Maximum Power Point Tracking \\
\hline $\operatorname{Cos} \alpha$ & Power factor \\
\hline$V_{\mathrm{dc}}$ & voltage required by DC side \\
\hline Idc & current required by DC side \\
\hline $\mathrm{V}_{\mathrm{ac}}$ & voltage required by $\mathrm{AC}$ side \\
\hline Iac & current required by AC side \\
\hline$\eta$ & Efficiency \\
\hline VTHD & Voltage total harmonic distortion \\
\hline Ітно & Current total harmonic distortion \\
\hline$\eta_{\mathrm{R}}$ & Rated output efficiency (\%) \\
\hline$P_{i}$ & Rated input power to SPV inverter at rated output $(\mathrm{kW})$ \\
\hline Po & Rated output power from SPV inverter $(\mathrm{kW})$ \\
\hline $\mathrm{D}$ & Duty cycle \\
\hline $\mathrm{V}_{\mathrm{L}}$ & Inductor voltage \\
\hline Vs & Source voltage \\
\hline $\mathrm{V}_{0}$ & Output voltage \\
\hline iL & Inductor current \\
\hline ZVT & Zero voltage transition \\
\hline ZCS & Zero current switching \\
\hline ZVS & Zero voltage switching \\
\hline DC & Direct current \\
\hline $\mathrm{AC}$ & Alternate current \\
\hline
\end{tabular}


1 Introduction: The cumulative imbalance in atmosphere due to consumption of non-renewable energy sources which continuously leads to environmental degradation and therefore, the researchers investigate environment friendly and clean renewable energy resources. Solar energy is becoming progressively important and now established for various technologies, which is responsible for appropriate selections to electricity users to receive power from the grid source and can supply power to grid in order to achieve individual user demands and alternatively to be a power producer as they can easily supply extra power to grid as well by the concept of grid fed. Solar power converters are unique in design and cost effective renewable energy resource. Solar power converters, being able to convert the energy direct coming from sun through solar photovoltaic modules convert into electrical energy using various conversion approaches. Understanding the concept of electronics devices such as diode and transistors and also the voltage and current relationship for linear devices [1], [2]. Improvements in high voltage gain DC-DC converter [3] to attain high efficiency and output power. [4], [5], [6]. Study of different technologies of transformer-less converters through high step up voltage gain, steady analysis and detailed discussion on boundary operating conditions [7], [8]. The solar power converters proposed the features of light weight, lesser cost, easy and noiseless operation which results in improved life, better reliability and less maintenance [9]. The lack of presence of experimental values on total power consumption with comparative analysis of different technologies of solar power converters motivates the researchers to work more. Therefore, the principle operation of the circuit is to control the strategies and features of overall system. Study their characteristics in detail as simulation and experimental outcomes are presented to validate hypothetical investigation [10].

Research efforts in components and behavioural analysis of different technologies of DC-DC converters like sepic, flyback and cuk in order to increase the efficiency are underway [11], [12], [13], [14], and [15]. By analysing the circuit geometry of power converters comes under the approach of improving the performance of existing converters. The DC-DC boost converter and ZVS \& ZCS operation have been investigated by many researchers [16], [17-24]. Bascope, et al. [25] analysed the performance of different topologies of DC-DC converters i.e. buck, boost, buck-boost, cuk, sepic and zeta then proposed a new converter with high power and low current ripple. However, the proposed design of the circuit is more complex. Kim et al. [26] proposed the development in designing of the coupled inductor using ideal coupling coefficient in order to attain the reduced ripple current. Therefore, to discover the optimal coupling coefficient, inductor (L1, L2) current ripple by analysing the optimal circuit. Yang and He [27] presented a solar photovoltaic system with high efficiency connected with utility grid. The suggested photovoltaic power system can work robustly using high efficient zero voltage transition incorporated with high step up DC-DC converter using coupled inductors, windings and vigorous clamp circuits are the prime control stage. The concept of High voltage gain is attained by turn ratio selection of winding- 
coupled inductors which represents good performance. Ismail et al. [28] developed a novel concept of high voltage single switch pulse width modulation (PWM) based DC-DC converter by means of reduced switching stress. Suggested converter development was analysed in both continuous as well in discontinuous conducting modes. PWM technique is used to regulate the converter at constant frequency. Evaluations prepared among the proposed technologies and additional recommended high step up voltage gain topologies. Lopes and Naguib [29] carried out research on space vector modulation technique on current source converter.

Franceschini et al. [30] proposed a single phase grid connected converters based on d-q frame current control technique then compared the correctness of the advised grid connected converter SIMULINK/MATLAB outcomes with experimental results. The converter also been experienced with PI regulator then by the results of both cases the proposed $\mathrm{d}$-q based current control converter demonstrates improved steady state performance and less current total harmonic distortion. Ahmed et al. [31] recommended analytical current controller which is capable to provide high power quality and has developed better bandwidth later it controls in a static frame. The foremost shortcoming was the dependency on parameters as well as acute towards noise. Simulated and experimental values have validated the current controller and then eliminates steady-state errors, which helps to get better power quality, also performance of the proposed system with less than $1 \%$ of the total current distortion. Fathabadi [32] proposed a system with battery charger which is consist of an efficient step up DC-DC converter and a voltage controller with DC link. He also proposed an inverter based on PWM technique with efficient maximum power point tracking system (MPPT). Tsang and Chan [33] suggested a sixswitch AC-AC converter with single phase grid-connected interface. This resulted some new switching techniques like simulated response in $\mathrm{AC}$ to $\mathrm{DC}$ conversion system decoupling with $\mathrm{DC}$ to $\mathrm{AC}$ conversion arrangement using such converters can effectively have aimed at improved efficiency for the converters. Two controllers are measured to regulate the input AC-DC power supply system using output DC-AC regulated system. Some investigational values shown used for the demonstration of the effectiveness of the suggested converter.

Based on the recent research, it is clear that the study of various technologies of DC-DC converters using renewable energy source has been presented comprehensively. Prior to the study on various DCDC high step up converters for different applications has involved analysis of the types of switched inductors and capacitors [34], [35] and [36], at high output voltage applications switching power losses occur [37]. However, these studies do not consider the quality and performance evaluation using international standard [38] and cost analysis according to Indian households. In the present study, high power converter practice is used to improve output voltage of the $12 \mathrm{~V}$ input dc source to dc interface 
system towards the utility grid source through DC to AC conversion system. Distinct solar photovoltaic module [39] using fuel cell energy conversion method [40], [41] and [42] are predominantly low voltage source applications and therefore high voltage gain boost converter is necessary to normalize the voltage of the DC-DC interface. The effect of the other parameters for instance input power and output power, total harmonic distortion, power factor on the device performance has been discussed as well.

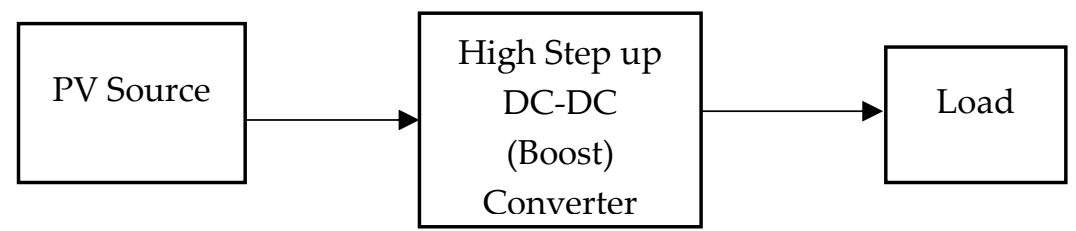

Fig 1: Solar Photovoltaic system using DC-DC converter

There are three technologies of high efficiency converters are used with solar photovoltaics as an input power source:

1. Solar PV based Boost Converter (high step up DC-DC converter).

2. Solar PV DC-AC converter (inverter).

3. High efficiency proposed Solar PV DC-DC converter.

1.1 Solar PV based Boost Converter (high step up DC-DC converter): This device is based on power electronics power conversion technique as low input dc voltage converted to high voltage output dc by means of regulated power method as given in Fig 1. The high step up DC-DC (boost) converter [43] is a switch based power converter that controls opening and closing of the circuit periodically using electronic switches. This device is characterised as a boost converter for the reason that the output voltage is larger than the input voltage. The inductor current present in the circuit is continuous i.e. always positive, a large capacitor which controlled the output voltage to maintain constant at voltage Vo.

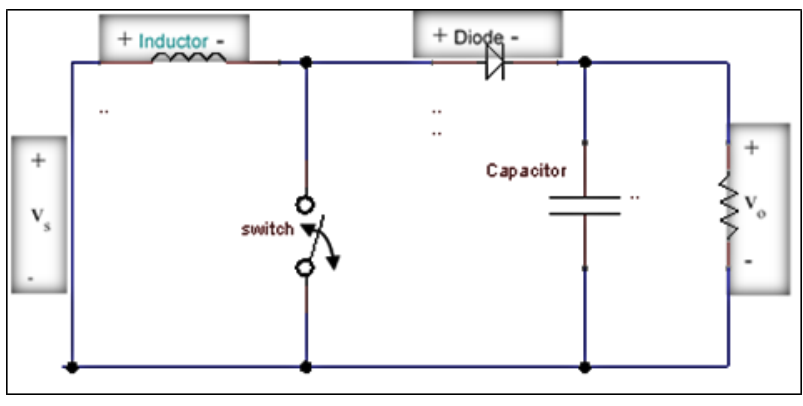

Fig. 2: Equivalent circuit of boost (high step up DC-DC) converter

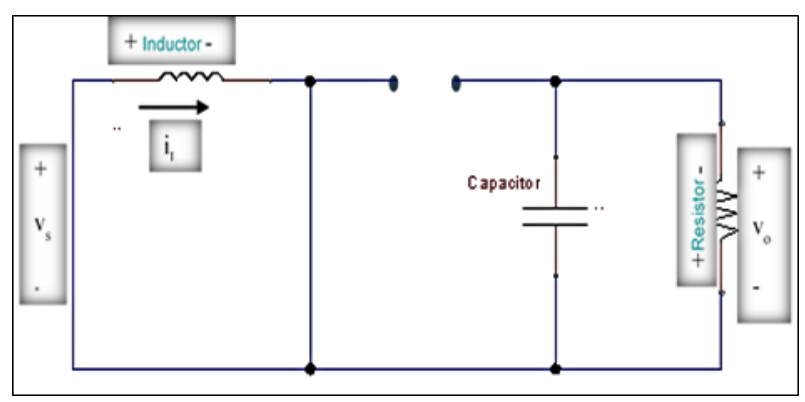

Fig. 3: Equivalent circuit of boost (high step up DCDC) converter in close switch condition Converter switch closed condition 
The high voltage gains (boost) converter as shown in Fig. 2 with switching period and duty cycle.

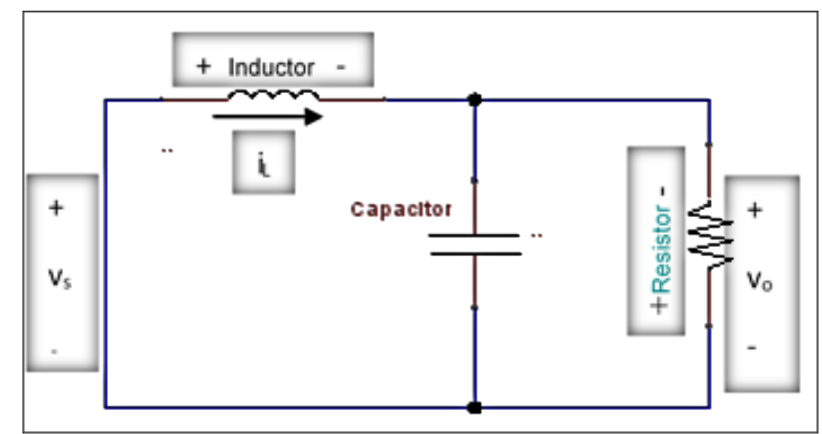

Fig. 4: Equivalent circuit of boost (high step up DC-DC) converter in open switch condition

Switch close condition analysis of a high step up DC-DC converter: In closed switch state, diode is in reverse bias condition as shown in Fig.3. Conferring to Kirchhoff's law of voltage, the voltage around the path containing the source, inductor and closed switch is given by the equation given below:

$$
V_{L}=V_{S}=L d i_{L} / d_{t}
$$

The ratio of change in current is held constant therefore, the gain in current is linear despite the fact that the switch is in closed condition,

$$
\begin{aligned}
& \frac{\Delta i_{L}}{\Delta t}=\Delta i_{L} / D T \\
& \left(\Delta i_{L}\right) \text { closed }=V_{S} * D * \frac{T}{L}
\end{aligned}
$$

Switch open condition analysis of a high step up DC-DC converter: In switch open state, as shown in the circuit diagram of Fig. 4, the inductor current can't be change immediately. Hence, diode turn out to be in forward bias state in order to provide a smooth path for inductor current and the voltage across the inductor is given by the equation (4), assuming that the $V_{o}$ (output voltage) is constant.

$$
V_{L}=V_{S}-V_{0}=L d i_{L} / d t
$$

Output Power,

$$
P_{0}=\frac{V_{0}^{2}}{R}=V_{0} * I_{0}
$$

The rate of change in inductor current is constant. Hence, when the switch is open, the change in current is linear. Therefore, the output voltage is known by the equation given below:

$$
V_{0}=\frac{V_{S}}{(1-D)}
$$


This MATLAB SIMULINK model presents in Fig. 5 represents a high gain DC-DC conversion in order to enhance the dc output voltage level with respect to input dc source close to an accurate and smooth voltage which is used for dc interface across the high voltage gain (DC-DC) converter towards the main electrical grid. Suggested DC-DC converter is a high step up power converter using coupled capacitor and having efficiency of $99.83 \%$.

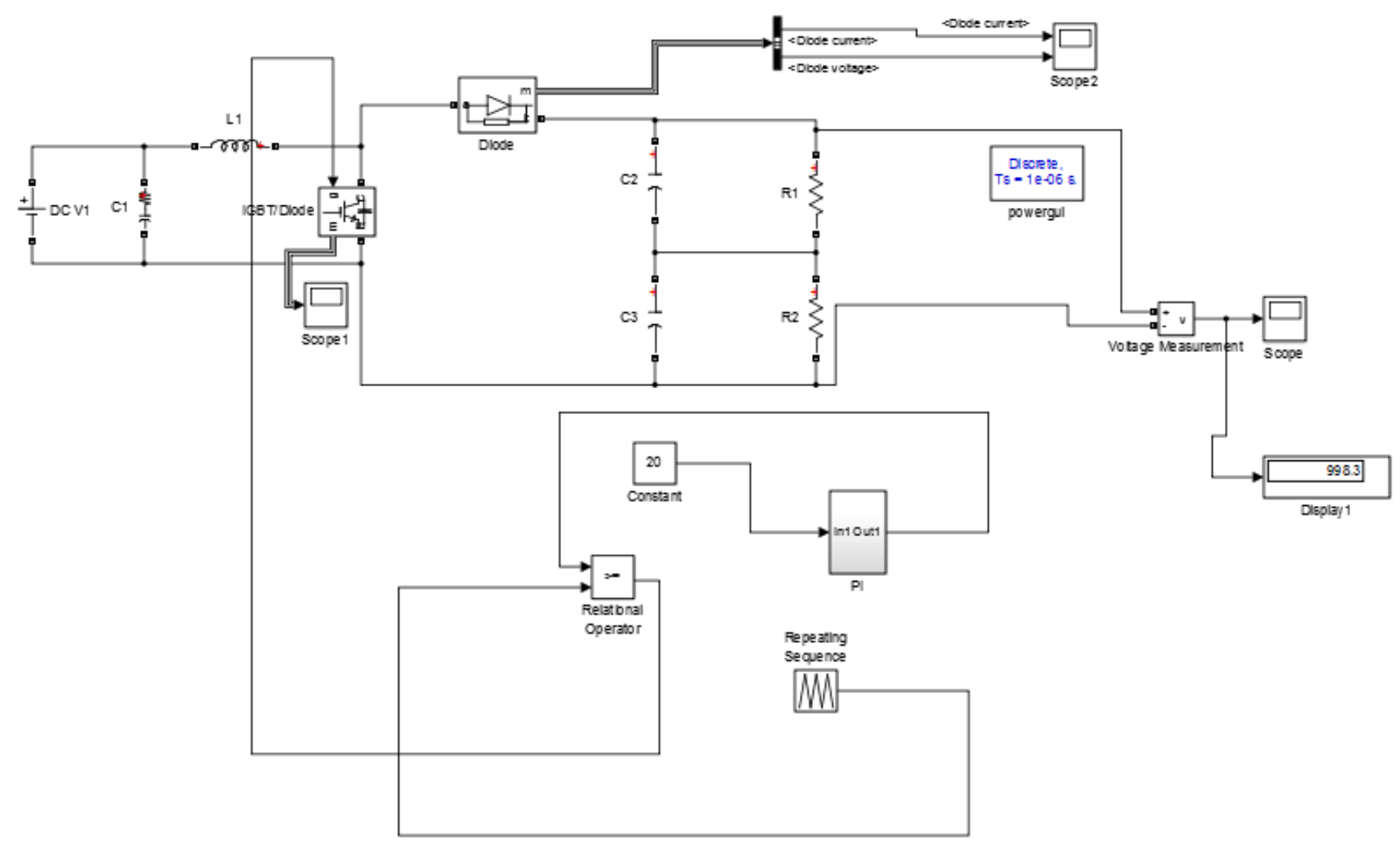

Fig. 5: MATLAB SIMULINK model showing a 12V DC-DC converter having efficiency of $99.83 \%$

On average efficiency: 100 Watt of system having average efficiency $77.67 \%$ and consumes 129 watts in 1 hour and for 1 hour we need 10.75 Ah battery and for 10 hours we need 107.5 Ah battery.

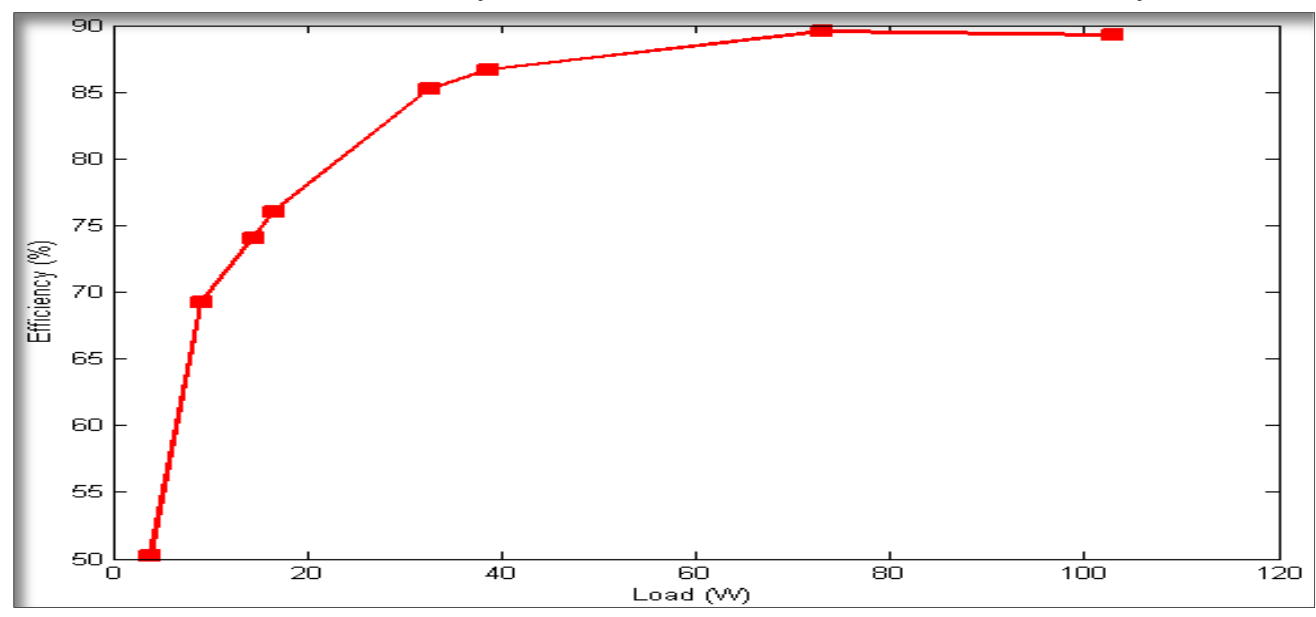

Fig. 6: Graph between Load and Efficiency for 12 V DC System 
Eff at max load: 100 Watt of system having efficiency at max load 89.26\% and consumes 112 watts in 1 hour and for 1 hour we need 9.33 Ah battery and for 10 hours we need 93.33 Ah battery. The graph between load and efficiency as given in Fig. 6, shows the efficiency of the system according to the load and input power is also calculated.

1.2 DC-AC converter or (OFF Grid) Standalone inverters: DC-AC converters or inverters are practised in insulated environment where such types of converters can easily draw dc power coming from batteries charged by using solar photovoltaic modules. In general, OFF Grid inverters do not have the feature to interface with the main electricity grid supply but now such inverters are designed to take dc power from PV and batteries and some additional sources like utility grid, generator set, hydro and wind turbines etc. only applicable to specially designed systems. Several OFF grid inverters also integrated with battery chargers to replace batteries from source according to the availability. A very basic OFF Grid inverter generally don't have a special feature to take power from utility grid. Therefore, such inverters do not require anti-islanding protection. Inverters with battery storage and grid fed features exist and such systems are particularly aimed to draw energy from battery bank as well as use power from grid supply and they are termed as OFF Grid Hybrid inverters. These types of systems are able to charge batteries with the help of on board charger setup and can distribute additional power to main electrical grid feeder only if they grid fed feature. An OFF Grid inverter is capable of distributing ac power to various loads without difficulty. A block diagram with operational algorithm of a standalone inverter is shown in Fig. 7 \& 8 respectively.

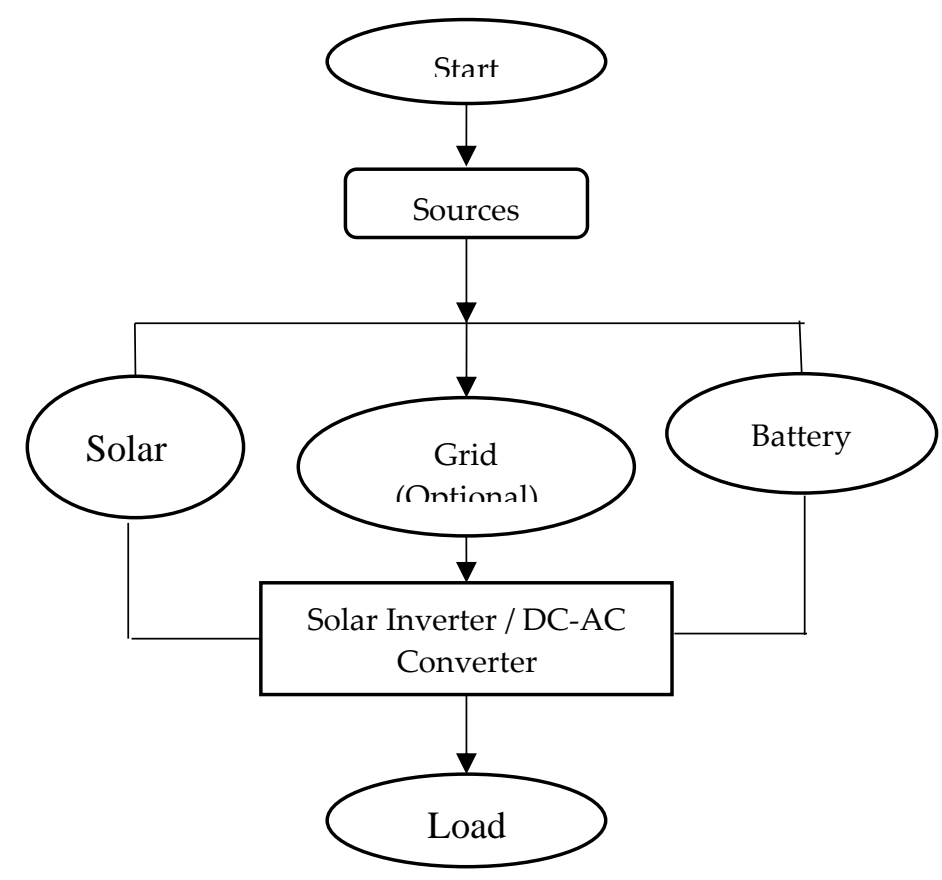

Fig. 7: DC-AC Converter 
Solar Panels

AC Loads
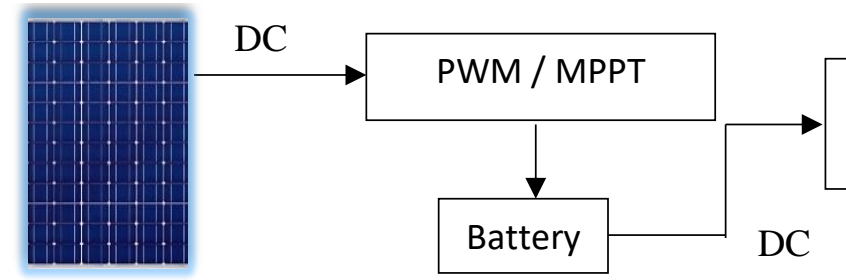

Fig. 8 Algorithm for Off Grid Inverter

Efficiency calculations: The concept of efficiency is measurable and it is quantitatively determined by the ratio of valuable work performed by the machine or performed in a process to the total energy consumed or heat taken in or the ratio of useful output to the input Table 1 shows the parameters calculated for performance evaluation of an inverter.

$$
\text { Efficiency }=(\text { Output measured / Input Measured }) * 100
$$

The rated output efficiency calculation from the measured data is given below:

$$
\eta_{\mathrm{R}}=\left(\mathrm{P}_{\mathrm{o}} / \mathrm{P}_{\mathrm{i}}\right) * 100
$$

Where,

$\mathrm{Po}_{\mathrm{o}}$ is the rated output power from power conditioner $(\mathrm{kW})$,

$\mathrm{P}_{\mathrm{i}}$ is the input power to power conditioner at rated output $(\mathrm{kW})$,

$\eta_{\mathrm{R}}$ is the rated output efficiency (\%).

\begin{tabular}{|c|c|c|}
\hline Sr. No. & Input & Output \\
\hline 1. & Voltage $\left(V_{\text {in }}\right)$ & Voltage ( $\left.V_{\text {out }}\right)$ \\
\hline 2. & Current $\left(\mathrm{I}_{\text {in }}\right)$ & Current (Iout) \\
\hline 3. & Power $\left(P_{\text {in }}\right)$ & Power (Pout) \\
\hline \multirow[t]{2}{*}{4.} & Total Harmonic Distortion (THD) (ІтнD) & Total Harmonic Distortion (THD) (ITHD) \\
\hline & $\&\left(\mathrm{~V}_{\mathrm{THD}}\right)$ & $\&\left(\mathrm{~V}_{\mathrm{THD}}\right)$ \\
\hline 5. & Power factor (Pf) & Power factor (Pf) \\
\hline 6. & NA & Frequency \\
\hline 7. & NA & Efficiency \\
\hline
\end{tabular}

Table 1: Parameters calculated in an inverter for the calculation of efficiency of the system

On average efficiency: 100 Watt of system having average efficiency of $71.57 \%$ and consumes 140 Watts in 1 hour and for 1 hour we need 12 Ah battery and for 10 hours we need 116.67 Ah battery. Efficiency at maximum load:100 Watt of system having efficiency of $86.26 \%$ at maximum load and consumes 116 
Watts in 1 hour and for 1 hour we need 9.66 Ah battery and for 10 hours we need 96.66 Ah battery. The graph between load and efficiency as shown in Fig. 9

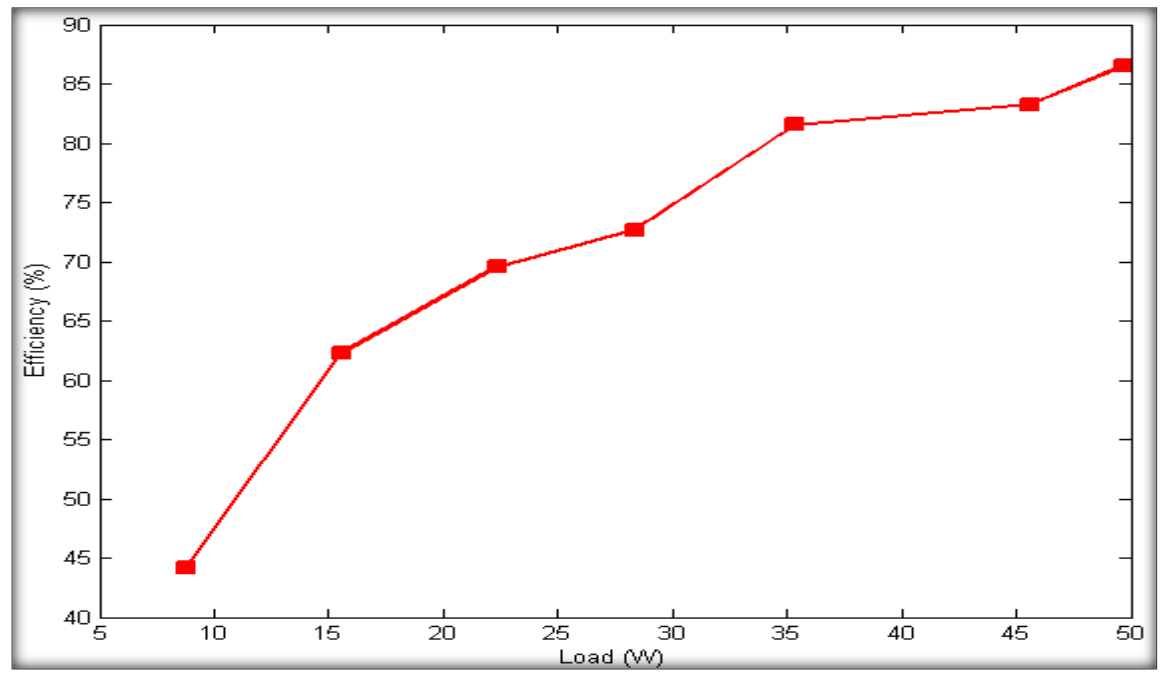

Fig. 9: Graph between Load and Efficiency for 12 V AC System

1.3 Solar PV High efficiency proposed DC-DC converter: A high step up solar photovoltaic based buck-boost converter [44]. A buck-boost converter can be obtained by cascade connection of the two basic converters as shown in Fig. 10:

- Buck converter (step-down converter) [45]

- Boost Converter (step-up converter)

Hence, the operation of the given circuit is explained in two modes. In first condition or mode 1, switch is turned on and the function of the diode is reverse biased. Hence, input current increases instantaneously and flows through the inductor and switch. During mode 2 state, switch is in turned off state and the flow of current continues towards the inductor, capacitor, diode and load. The energy stored in this particular mode through the inductor and is transferred to the load and the inductor current (iL) falls till the switch $S$ is turned on again in the next phase.

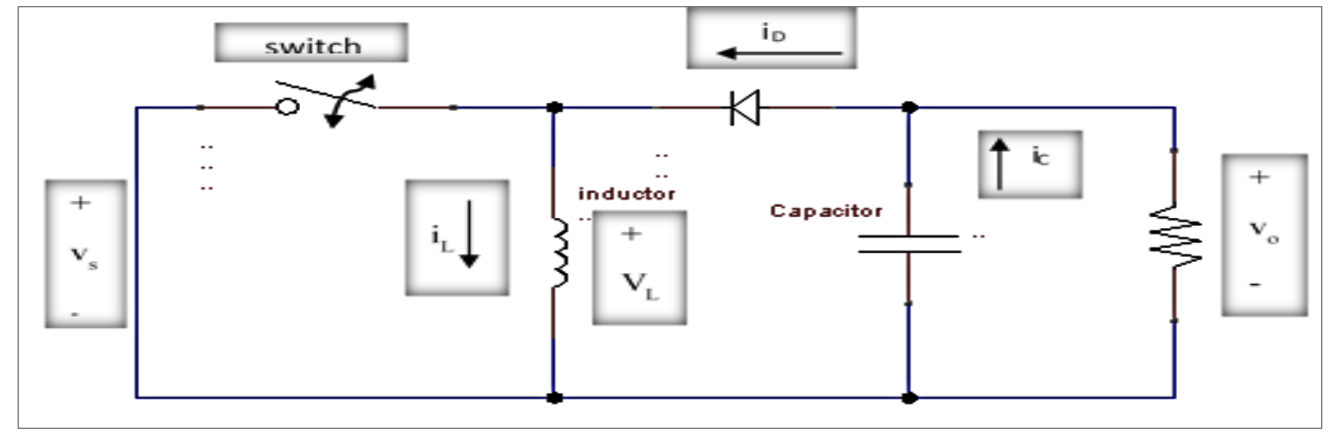

Fig. 10: Circuit Design of Buck-Boost (DC-DC) converter

Analysis for switch closed condition: While the switch is in closed state as shown in Fig. 11, the inductor voltage is given by the equation: 


$$
V_{L}=V_{S}=L * d i_{L} / d t
$$

The rate of change in inductor current is constant and inductor current starts increasing linearly. Therefore, the preceding equation for switch close condition is expressed as:

$$
\left(\Delta i_{L}\right) \text { closed }=V_{S} * D * \frac{T}{L}
$$

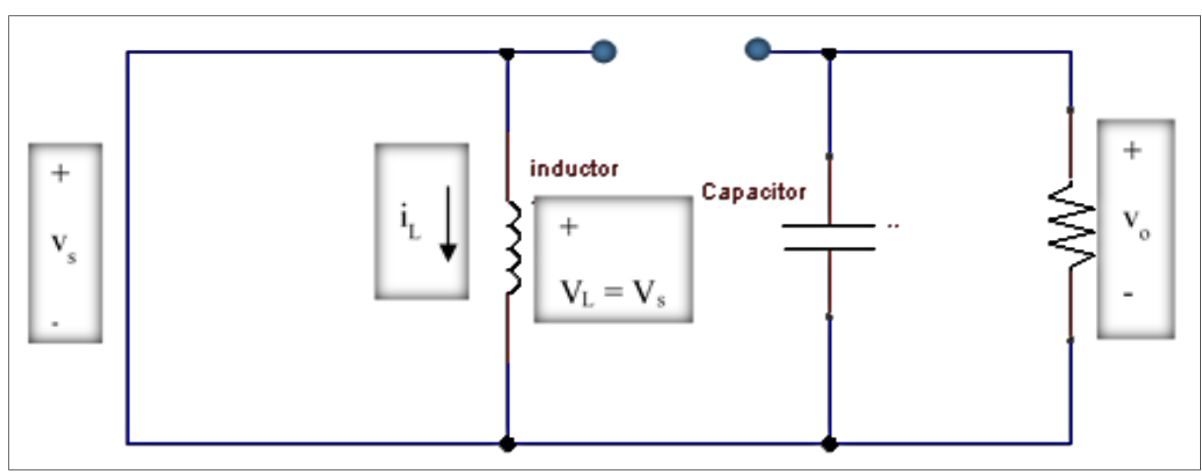

Fig.11: Circuit design of Buck-Boost (DC-DC) Converter switch closed

Analysis for switch open condition: In the switch open state as shown in Fig. 12, the current in the inductor cannot change immediately and resulted into forward biased state of the diode and the voltage across the inductor shows through equation (11) and (12).

$$
\begin{aligned}
& V_{L}=V_{o}=L * d i_{L} / d t \\
& \left(\Delta i_{L}\right) \text { open }=V_{O}(1-D) * \frac{T}{L}
\end{aligned}
$$

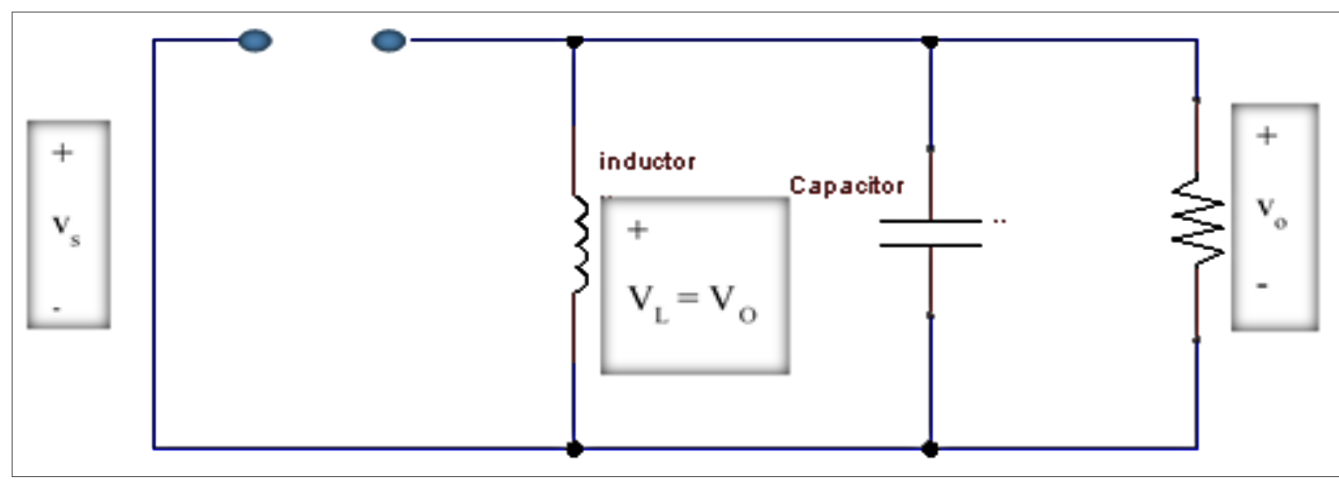

Fig. 12: Circuit design of Buck-Boost converter (DC-DC) switch open condition

Hence, using equation $10 \& 12$ we get,

$$
\begin{aligned}
& \left(\Delta i_{L}\right) \text { closed }+\left(\Delta i_{L}\right) \text { open }=0 \\
& V_{O}=-V_{S}[D /(1-D)]
\end{aligned}
$$

On average efficiency:100 Watt of system having average efficiency of $91.71 \%$ and consumes 109 Watts in 1 hour and for 1 hour we need 9.08 Ah battery and for 10 hours we need 90.83 Ah battery. Efficiency 
at maximum load: 100 Watt of system having efficiency at maximum load of $93.20 \%$ and consumes 107.29 Watts in 1 hour and for 1 hour we need 8.94 Ah battery and for 10 hours we need 89.40 Ah battery. The graph between load and efficiency as shown in Fig. 13.

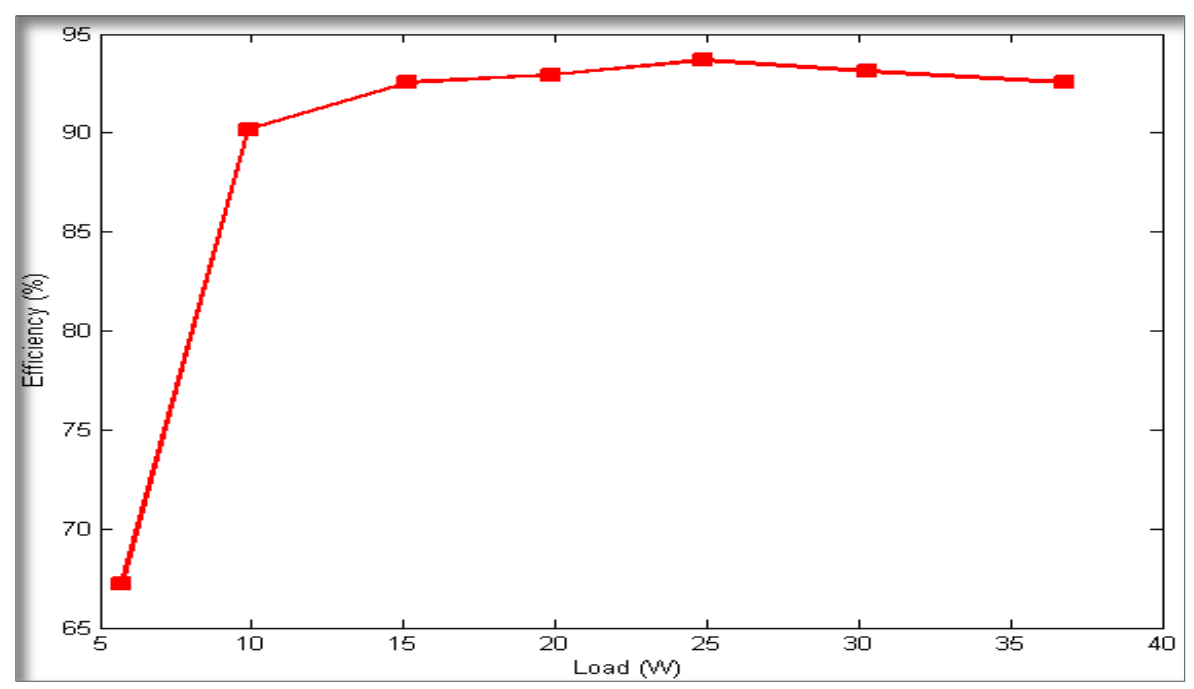

Fig. 13: Graph between Load and Efficiency for 12 V DC System

2 Approach: This research emphasis on meeting the gap of carrying out a development analysis of rural electrification and evaluating the socio economic effect of electrification. This study intends to identify the extreme strategies used to implement the policies which is accurate in the physical world. The main advantage of solar converters, it can be potentially low-cost, light-weight and able to design easily with improved efficiency for large volume production in the industry. These converters are also ideal for use in camps, houses which might have structures that can only support lighter weights or the areas where modules need to be folded, moved or kept away once module are not in use. The targets achieved in this project will encourage to use these solar converters for applications like chargers for cell phones, solar lanterns, laptop bags, etc.

3 Experimental setup: The Power Electronics test facility established at National Institute of Solar Energy mainly consists of a Solar Array Simulator 15Kw, Digital oscilloscope DPO 4034, Power Analyzer (Zimmer) 4 Channels shown in fig. 14 (a), (b) and (c) respectively. Three different technologies are installed and with actual loads and evaluate the performance as per IEC 61683. Digital Oscilloscope and Power Analyzer are installed in the facility for a continuous monitoring and records all the parameters including voltage, current, power input side as well as output side and efficiency of the system. 


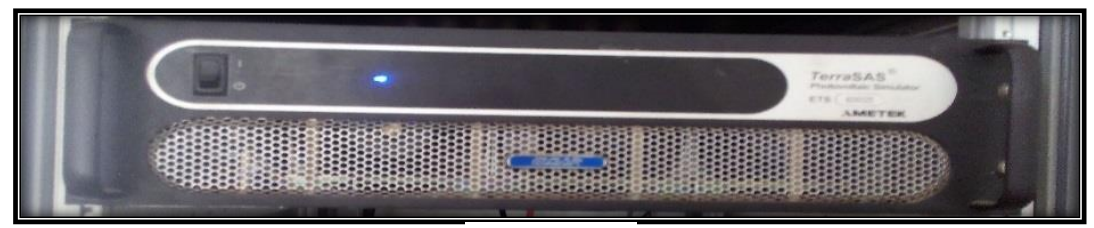

(a)

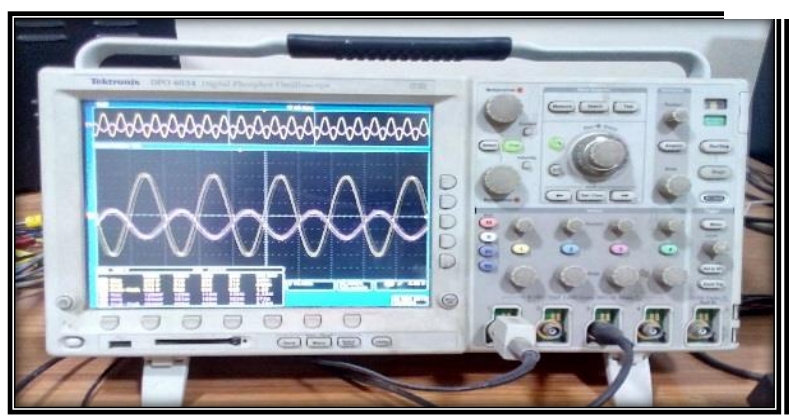

(b)

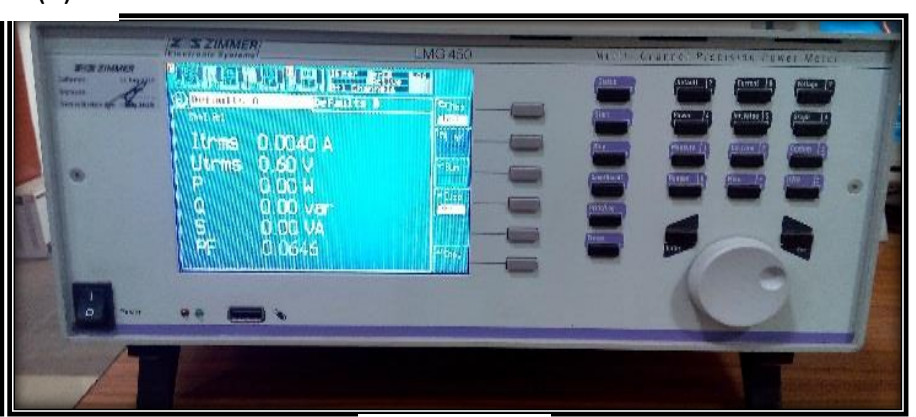

(c)

Fig.14: (a) Solar Array Simulator 15 kW, (b) Digital oscilloscope DPO 4034, (c) Power Analyzer (Zimmer) 4 A very basic Household loads consists of 3 LED bulbs, 20-watt tube light, one fan and 1 TV set. Three technologies i.e. High step up DC-DC boost converter, DC-AC converter, and High efficiency proposed DC-DC converter of solar converter units have been analysed by measurements concerning their efficiency and correspondingly compare the performance of these systems in terms of load, input power and the efficiency of the converters.

PV systems of 12 volts, low voltage DC, high voltage DC and AC system. For cutting down consumption and simplicity of user appliance we need to come with the use of LED based applications and are drawn by SMPS based supply. They can operate in both made high voltage DC above 110V and as well as 230V AC. By providing both way operation on DC and AC. Efficiency of system and reliability of system can be improved. Advantages of DC systems over AC systems like DC system generates power which is free from Pollution having low maintenance and operation cost as well as no supply limitations. There is a requirement to provide power to the low income group or in the areas where Grid supply is irregular. A Solar power solution of high efficiency which can use existing end equipment's like LED Bulbs, TV, Mobile charger, Fan etc. are the requirements.

4 Economic Analysis: Electrification in rural areas resulted in socioeconomic developments, also country dwellers are now able to operate electric appliances and devices and utilize renewable energy sources efficiently intended for expediency and also for the learning and education of their children. In this paper we proposed five functional values as shown in Fig. 15. 


\section{Functional Values}

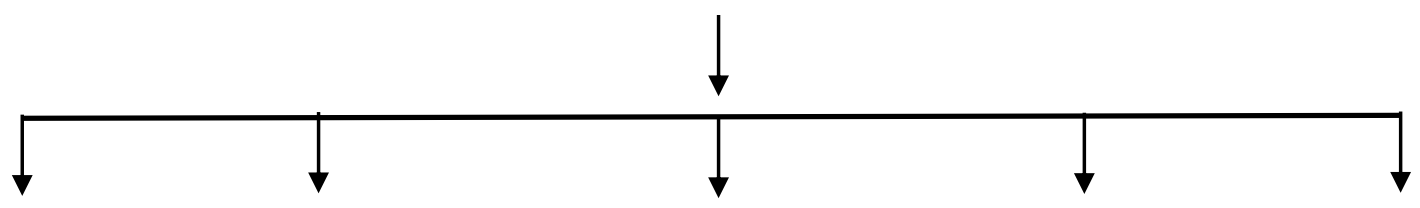
Economy Quality and Performance
Service
Time Management
Safety
(Cost)
(Meets Demand)
(Ease of Maintenance)
(Time Saving)
(Protection)

Fig. 15: Flow chart of functional values

For renewable energy generation, it is necessary to integrate power electronics segments to make improvement in power source, for instance semiconductors, switching devices, filters, heat sinks and some additional components like voltage and current sensors, various low voltage power supplies, housekeeping equipment's, control circuits etc. these tends to scale with power the Table 2 and Table 3 given below shows the procedure and performance analysis of the proposed three solar power converters respectively.

Table 2: Procedure and Requirements

\begin{tabular}{ccc}
\hline Sr. No. & Procedures & Requirements \\
\hline 1 & 3 LED Lights of 5W & 8 hours per Day \\
2 & Mobile Charger 6W & 4 hours per day \\
3 & Ceiling Fan AC/DC, & 6 hours per day \\
4 & TV 30W & 2 hours per day \\
5 & Working hours & $6-10$ PM, 5-7AM \\
6 & Idle or No load condition & 16 hours \\
\hline
\end{tabular}

Table 3: Performance \& system configurations against test results

\begin{tabular}{|c|c|c|c|c|}
\hline \multirow[t]{4}{*}{ S.No. } & \multirow{4}{*}{$\begin{array}{c}\text { Fan Type Used } \\
\text { Technologies/Power } \\
\text { Consumption }\end{array}$} & \multirow{4}{*}{$\begin{array}{l}\text { AC Induction FAN } \\
\text { 12V, High efficiency } \\
\text { DC-AC Converter }\end{array}$} & \multicolumn{2}{|c|}{ DC BLDC FAN } \\
\hline & & & \multirow{3}{*}{$\begin{array}{c}12 \mathrm{~V}, \text { High } \\
\text { efficiency DC-DC } \\
\text { Converter }\end{array}$} & \multirow{3}{*}{$\begin{array}{c}\text { 12V High Efficiency } \\
\text { Proposed DC-DC } \\
\text { Converter }\end{array}$} \\
\hline & & & & \\
\hline & & & & \\
\hline 1. & No Load Condition in & 6.27 & 6.27 & 0.13 \\
\hline & Watt for $16 \mathrm{hr}$ & & & \\
\hline 2. & $\begin{array}{l}\text { for } 2 \text { LED bulbs \& Run } \\
\text { time } 4 \mathrm{hr}\end{array}$ & 16.42 & 16.42 & 12.16 \\
\hline 3. & $\begin{array}{l}\text { For } 1 \text { Bulb \& } 1 \mathrm{TV} \text {, Run } \\
\text { time } 2 \mathrm{hr}\end{array}$ & 38.05 & 38.05 & 32.91 \\
\hline 4. & $\begin{array}{l}\text { For } 5 \text { Bulbs, } 1 \mathrm{TV} \text {, 1Fan } \\
\text { (DC), } 2 \mathrm{hr}\end{array}$ & 0.001 & 92.17 & 80.93 \\
\hline
\end{tabular}


5. For 2 Bulbs, $1 \mathrm{TV}, 1$ Fan

127.32

0.001

0.001

(AC), $2 \mathrm{hr}$ (Not taking startup load for 5 bulbs)

+3 bulb

6. Fan $\mathrm{AC}$ or $\mathrm{DC}$ as per 70.76

34.77

28.05

product type Rune time $4 \mathrm{Hrs}$

7. Total Power required in 779.69

565.43

390.60 Watt-hr

\section{System Configuration}

8. $\quad$ Required Panel Wattage $173.27 \quad 125.65 \quad 86.80$ $@ 4.5 \mathrm{~W}-\mathrm{Hr}$ for above Load per day

9. Required $12 \mathrm{~V}$ Battery 129.95

94.24

65.10

Ah for $50 \%$ autonomy

Table 4: Cost analysis as per the performance \& system configurations against test results

\begin{tabular}{|c|c|c|c|c|}
\hline S.No. & Financial plan & $\begin{array}{c}\text { DC-AC converter or } \\
\text { (OFF Grid) } \\
\text { Standalone inverters }\end{array}$ & $\begin{array}{l}\text { High efficiency } \\
\text { proposed DC-DC } \\
\text { converter }\end{array}$ & $\begin{array}{l}\text { High step up } \\
\text { DC-DC boost } \\
\text { converter }\end{array}$ \\
\hline 1. & $\begin{array}{l}\text { Cost of Panel @INR } \\
\text { 45/Watt }\end{array}$ & 7796.94 & 5654.28 & 3905.97 \\
\hline 2. & $\begin{array}{l}\text { Battery Cost @INR } \\
\text { 70/Ah }\end{array}$ & 9096.43 & 6596.66 & 4556.96 \\
\hline 3. & System & 5000 & 5000 & 1300 \\
\hline 4. & System Cost in INR & 21893.36 & 17250.93 & 9762.93 \\
\hline 5. & $\begin{array}{l}\text { Relative Cost per unit in } \\
\text { INR }\end{array}$ & 1.27 & 1.00 & 0.57 \\
\hline
\end{tabular}

The above given Table: 4 suggests a constant incremental relative cost per att. The implementation of the proposed high efficiency dc-dc converter based on solar photovoltaics facilitates the Indian household loads without doing any harm in our environment. The convergence of these three technologies shows the practical analysis, these converters having low maintenance, low-cost and efficient to normal household loads. The low cost, positive returns on investment, and use of international and national standards for the quality and performance analysis. There is a significant change in the operating approach for all the physical constraints. It offers a range of operating possibilities that have never been available before. Progressive procedures for the smart distribution utility grid becomes a reality in solar photovoltaics. 
5 Results and Discussion: There is a requirement to provide power to the low income group or in the areas where Grid supply is irregular. A Solar power solution of high efficiency which can use existing end equipment's like LED Bulbs, TV, Mobile charger, Fan, Computer, Laptop etc., is the requirement. Apart from real time data and testing Simulink Model of the first technology i.e. 12 V DC System is simulated and that model shows efficiency of $99.83 \%$ at full load. Table 5 given below shows the experimental test results of total power consumption by load.

Table 5: Total power consumption against test results

\begin{tabular}{|c|c|c|c|c|c|}
\hline \multirow[t]{2}{*}{ S,No. } & \multirow[t]{2}{*}{ Load } & \multirow[t]{2}{*}{ Quantity } & \multirow{2}{*}{$\begin{array}{l}\text { Power } \\
\text { (Watts) }\end{array}$} & \multicolumn{2}{|c|}{ Total Power Consumption (Watts) } \\
\hline & & & & Notional Values & $\begin{array}{l}\text { Experimental Values (2 } \\
\text { decimal) }\end{array}$ \\
\hline 1. & LED Bulb & 1 & 3 & 3 & 3.11 \\
\hline 2. & LED Bulb & 1 & 5 & 5 & 5.00 \\
\hline 3. & Fan & 1 & 20 & 20 & 21.20 \\
\hline 4. & LED Bulb & 1 & 7 & 7 & 7.06 \\
\hline 5. & LED Bulb & 2 & 10 & 20 & 10.45 \\
\hline 6. & LED Bulb & 3 & 5 & 15 & 15.14 \\
\hline 7. & LED Bulb & 4 & 5 & 20 & 19.87 \\
\hline 8. & LED Bulb & 5 & 5 & 25 & 25.04 \\
\hline 9. & LED Bulb + Fan & $3+1$ & $3+20$ & 29 & 30.13 \\
\hline
\end{tabular}

From above, DC system is having all benefits related to distances covered, efficiency, power conversion, minimum hardware, maintenance, cost etc. with using all existing electrical equipment's except ceiling fan. All existing fans are consuming 70 to $150 \mathrm{~W}$ of power so to run, but for solar is a very costly affair by changing it to new fan, system cost is much lower. It is believed that DC system is more hazardous than AC, but it has been test-run at various sect of peoples working on it, the shock felt by person is very much lower than $230 \mathrm{~V}$ AC shock. It is due to uses lower voltage (130V) than AC which is $230 \mathrm{~V}$ with peak of $350 \mathrm{~V}$. In the Fig. 16 combined efficiencies of all the power converters using solar photovoltaics is given with different loads.

Uncertainty Measurement: Uncertainty evaluation of a result of the measured value is well defined as the margin of error of the measured quantity when clearly stated by a range of values approaching to enclose accurate calculation as shown in Table 7 which illustrates the standard uncertainty at full load and overall uncertainty limit based on the experimental values. 
Table 7: Total Uncertainty at full load and Uncertainty Limit

\begin{tabular}{|c|c|c|c|}
\hline $\begin{array}{l}\text { Sr. } \\
\text { No. }\end{array}$ & Converters & $\begin{array}{l}\text { Standard Uncertainty } \\
(\%) \text { at full load }\end{array}$ & Uncertainty Limit (\%) \\
\hline 1 & High step up DC-DC boost converter & 0.17 & 0.13 to 0.17 \\
\hline 2 & DC-AC converter & 0.24 & 0.14 to 1.98 \\
\hline 3 & $\begin{array}{l}\text { High efficiency proposed DC-DC } \\
\text { converter }\end{array}$ & 0.23 & 0.19 to 1.64 \\
\hline
\end{tabular}

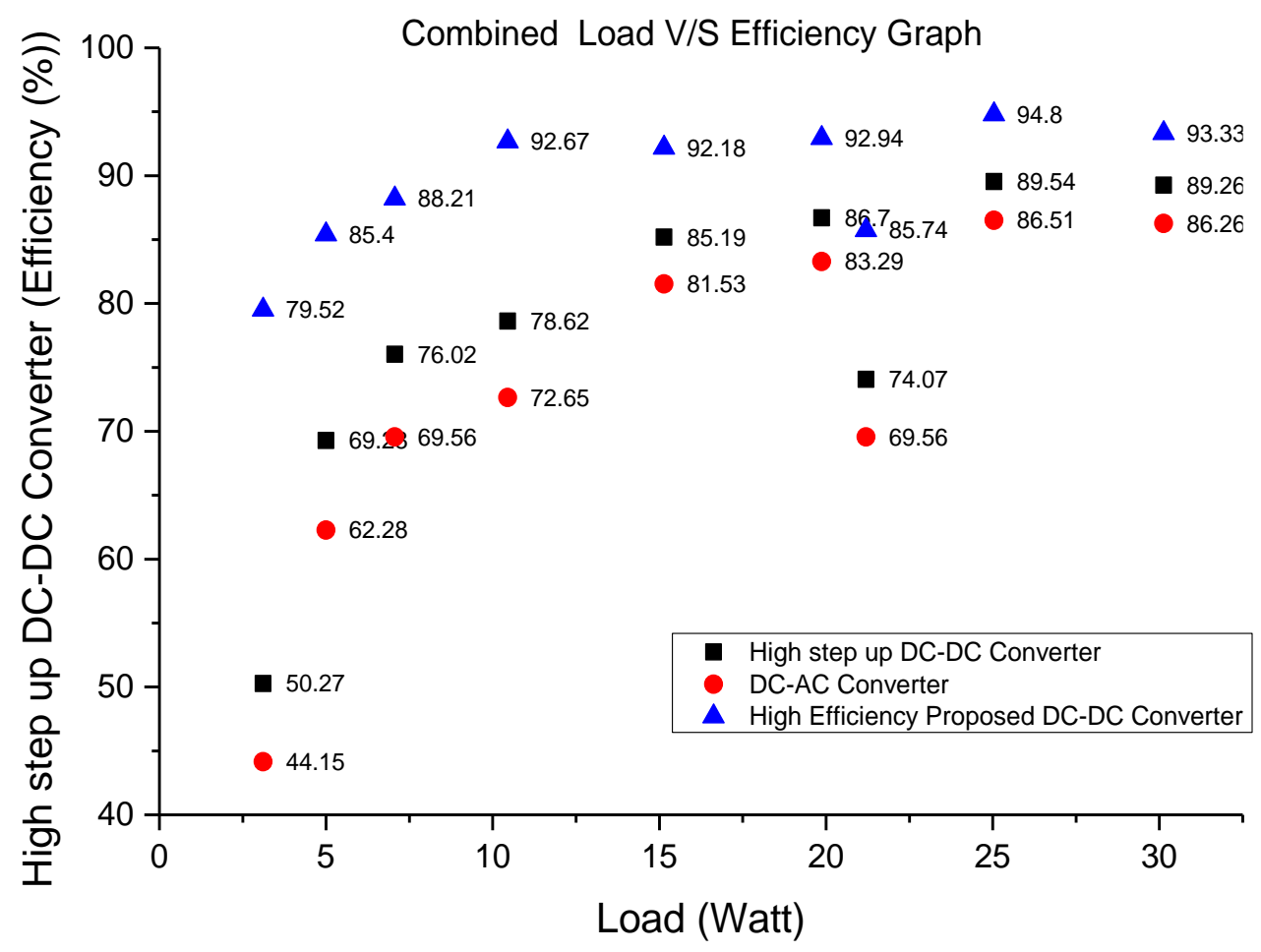

Fig. 16: Combined load v/s efficiency graph of all the three proposed converters

Table 6: Average efficiency and efficiency at full load

\begin{tabular}{cccc}
\hline Sr. & \multicolumn{1}{c}{ Converters } & Average Efficiency (\%) & Efficiency (\%) at full \\
No. & & & load \\
\hline 1 & High step up DC-DC boost converter & 77.67 & 89.26 \\
2 & DC-AC converter & 71.19 & 86.26 \\
3 & High efficiency proposed DC-DC & 88.89 & 93.33 \\
& converter & & \\
\hline
\end{tabular}

As the above given Table 6 shows the average efficiency and efficiency at full load of all the three solar power converters. Hence, from the above MATLAB results as well as from the experimental results with theoretical analysis shows that the High efficiency proposed DC-DC converter (12 V DC System) is better in among all the three technologies on the basis of load, input power and efficiency. 
6 Conclusions: The suggested high efficiency DC-DC converter is completely based on renewable energy source, cost and efficiency are two main issues in the field of renewable. Hence, the primary focus is to develop a system which is low-cost and highly efficient, fitting to our national mind-set and targeted to serve the necessities of those developing countries where electricity is limited or not able to reach, e.g. low cost and highly efficient DC-AC Converters or DC-DC converter based on Solar Photovoltaic. This research work identifies the technologies that enable the integration of renewable energy sources in the electric power system, power electronics, DC-DC converters, power management, power conversion and control for renewable energy interface, especially PV. The main features of the proposed converters include high efficiency and high voltage gain. The simplicity of its design have continuous input and output current. To conclude, the recommended concept can be prolonged without difficulty to other power transformation systems in order to achieve high-voltage demands.

Acknowledgement: The authors gratefully acknowledge the support of the National Institute of Solar Energy, Gurugram (India), for providing the necessary facilities to carry out this research work.

Conflict of Interest: On behalf of all authors, the corresponding author states that there is no conflict of interest.

\section{References:}

[1] N Mohan, T Undeland, W Robbins Power Electronics: Converters, Applications, and Design. New York: Wiley, 1995.

[2] Daniel W Hart, Power Electronics- Handbook, McGraw-Hill Higher Education, 2010.

[3] Shih-Ming Chen, Tsorng-Juu Liang, Lung-Sheng Yang, and Jiann-Fuh Chen, A Cascaded High StepUp DC-DC Converter with Single Switch for Microsource Applications, IEEE Transactions on Power Electronics, April 2011, 10.1109/TPEL.2010.2090362.

[4] Omar Abdel-Rahim, Mohamed Orabi, and Mahrous E. Ahmed, High Gain Single-Stage Inverter for Photovoltaic AC Modules, 978-1-4244-8085-2/11/\$26.00 @2011 IEEE.

[5] Lung-Sheng Yang, Tsorng-Juu Liang, Hau-Cheng Lee, and Jiann-Fuh Chen, Novel High, Step-Up DC-DC Converter with Coupled-Inductor and Voltage-Doubler Circuits, IEEE, Transactions on Industrial Electronics, September 2011, 10.1109/TIE.2010.2098360.

[6] Yi-Ping Hsieh, Jiann-Fuh Chen, Tsorng-Juu Liang, and Lung-Sheng Yang, A Novel High Step-Up DC-DC Converter for a Microgrid System, IEEE Transactions on Power Electronics, 10.1109/TPEL.2010.2096826. 
[7] Lung-Sheng, Yang, Tsorng-Juu Liang, and Jiann-Fuh Chen, Transformer less DC-DC Converters with High Step-Up Voltage Gain, IEEE Transactions on Industrial Electronics, 10.1109/TIE.2009.2022512.

[8] Sandeep Anand, Saikrishna Kashyap Gundlapalli, and B. G. Fernandes, Transformer-Less Grid Feeding Current Source Inverter for Solar Photovoltaic System IEEE, 10.1109/TIE.2014.2300038.

[9] Wuhua Li, Member, IEEE, and Xiangning He, Fellow, Review of Nonisolated High-Step-Up DC/DC Converters in Photovoltaic Grid-Connected Applications, IEEE, 10.1109/TIE.2010.2049715.

[10] Wenxin Huang, Ping Zhao, Yufei Zhou, Single-stage Boost Inverter for Photovoltaic System, 9781-4577-0541-0/11/\$26.00 @2011 IEEE

[11] Ching-Tsai Pan, Ming-Chieh Cheng, and Ching-Ming Lai, A Novel Integrated DC/AC Converter with High Voltage Gain Capability for Distributed Energy Resource Systems, IEEE, 2011.

[12] L.K. Wong T.K. Man, Small signal modelling of open-loop SEPIC converters, ISSN 1755-4535.

[13] Rong-Jong Wai, Rou-Yong Duan, High Step-Up Converter with Coupled-Inductor, 10.1109/TPEL.2005.854023.

[14] Roger Gules, Walter Meneghette dos Santos, Rafael Christiano Annunziato, Eduardo Felix Ribeiro, Romaneli and Cristiano Quevedo Andrea, A Modified Sepic Converter with High Static Gain for Renewable Applications, 978-1-4577-1646-1/11/\$26.00 @2011 IEEE.

[15] Emmanuel C. Tatakis, Margarita Kalogeropoulou and Georgios C. Christidis, Behavioral analysis of a single-switch step up converter.

[16] Bo Yuan, Xu Yang, Donghao Li, Yunqing Pei, Jason Duan, and Jerry Zhai, A Current-Fed Multiresonant Converter with Low Circulating Energy and Zero-Current Switching for High StepUp Power Conversion, IEEE Transactions on Power Electronics, 2011 1613, 10.1109/TPEL.2010.2097606.

[17] Yu Fang and Xudong Ma, A Novel PV Microinverter with Coupled Inductors and Double-Boost Topology, IEEE Transactions on Power Electronics, 201010.1109/TPEL.2010.2087417.

[18] Hyun-Lark Do, A Zero-Voltage-Switching DC-DC Converter with High Voltage Gain, IEEE Transactions on Power Electronics, 10.1109/TPEL.2010.2087038

[19] Suman Dwari, and Leila Parsa, Member, An Efficient High-Step-Up Interleaved DC-DC Converter with a Common Active Clamp IEEE Transactions on Power Electronics, 10.1109/TPEL.2010.2051816. 
[20] Luiz H. S. C. Barreto, Paulo P. Praça, Gustavo A. L. Henn; Raphael A.Câmara, Ranoyca N. A. L. S., Demercil S. Oliveira,High, Voltage Gain Boost Converter Battery Charger Applied to PV Systems, 978-1-4244-8085-2/11/\$26.00 @2011 IEEE

[21] Moustafa Mousa, Mohamed Orabi, Mahrous Ahmed, and Mohamed Youssef, High Voltage Gain Boost Converter Topology for Grid Connected Systems, 2, 978-1-4577-0541-0/11/\$26.00 @2011 IEEE.

[22] Rong-Jong Wai, Chung-You Lin, Rou-Yong Duan, and Yung-Ruei Chang, High-Efficiency DC-DC Converter with High Voltage Gain and Reduced Switch Stress IEEE, 10.1109/TIE.2006.888794.

[23] Gustavo A. L. Henn, R. N. A. L. Silva, Paulo P. Prac,a, Luiz H. S. C. Barreto, and Demercil S. Oliveira, Jr., Interleaved-Boost Converter with High Voltage Gain 10.1109/TPEL.2010.2049379.

[24] Esam H. Ismail, Mustafa A. Al-Saffar, Ahmad J. Sabzali, and Abbas A. Fardoun, High Voltage Gain Single-Switch Non-Isolated DC DC Converters for Renewable Energy Applications IEEE ICSET 2010 6-9 Dec 2010.

[25] R. P. Torrico-Bascope, and L. F. Costa, G. V. Torrico-Bascope, Generation of New Nonisolated High Voltage Gain DC-DC Converters, 978-1-4577-1250-01111\$26.00 @2011 IEEE.

[26] Kyu-Dong Kim, Jun-Gu Kim, Yong-Chae Jung, Chung-Yuen Won. Improved Non-isolated High Voltage Gain Boost Converter Using Coupled Inductors.

[27] Bo Yang, Wuhua Li, Yi Zhao, and Xiangning He, Design and Analysis of a Grid-Connected Photovoltaic Power System 10.1109/TPEL.2009.2036432.

[28] Esam H. Ismail, Mustafa A. Al-Saffar, and Ahmad J. Sabzali, High Conversion Ratio DC-DC Converters with Reduced Switch Stress 10.1109/TCSI.2008.918195.

[29] Luiz A. C. Lopes and Maged F. Naguib, Space Vector Modulation for Low Switching Frequency Current Source Converters with Reduced Low-Order Non characteristic Harmonics, 10.1109/TPEL.2008.2011270.

[30] G. Franceschini, E. Lorenzani, C. Tassoni, A. Bellini, Synchronous reference frame grid current control for single-phase photovoltaic converters, 978-1-4244-2279-1/08/\$25.00 @ 2008 IEEE.

[31] Khaled H. Ahmed, Ahmed M. Massoud, Stephen J. Finney, and Barry W. Williams, A Modified Stationary Reference Frame-Based Predictive Current Control with Zero Steady-State Error for LCL Coupled Inverter-Based Distributed Generation Systems 0278-0046/\$26.00 @ 2010 IEEE. 
[32] Hassan Fathabadi, Novel photovoltaic based battery charger including novel high efficiency stepup DC/DC converter and novel high accurate fast maximum power point tracking controller 10.1016/j.enconman.2015.12.025.

[33] K.M. Tsang and W.L. Chan, Direct AC-AC grid interface converter for ocean wave energy system, 10.1016/j.enconman.2014.12.059.

[34] Yi-Ping Hsieh, Jiann-Fuh Chen, Tsorng-Juu Liang, and Lung-Sheng Yang, Novel High Step-Up DC-DC Converter for Distributed Generation System, 97-2221-E-006-278-MY3, 2009.

[35] Yi-Ping Hsieh, Jiann-Fuh Chen, Tsorng-Juu Liang and Lung-Sheng Yang Novel High Step-Up DCDC Converter with Coupled-Inductor and Switched-Capacitor Techniques, IEEE Transactions on Industrial Electronics, 10.1109/TIE.2011.2151828VOL.

[36] Y.-P. Hsieh, J.-F. Chen, T.-J. Liang, L.-S. Yang, Analysis and implementation of a novel singleswitch high step-up DC-DC converter, ISSN 1755-4535.

[37] Woo-Young Choi, Ju-Seung Yoo, Jae-Yeon ChoiHigh, High Efficiency DC-DC Converter with High Step-Up Gain for Low PV Voltage Sources, 8th International Conference on Power Electronics ECCE Asia, 2011.

[38] IS/IEC 61683 - "Photovoltaic systems -Power conditioners-Procedure for measuring efficiency", 1999.

[39] Mario Cacciato, Alfio Consoli, Vittorio Crisafulli, A High Voltage Gain DC/DC Converter for Energy Harvesting in Single Module, Photovoltaic Applications 978-1-4244-6392-3/10/\$26.00 @2010 IEEE

[40] Rong-Jong Wai, Chung-You Lin, Chun-Yu Lin, Rou-Yong Duan, and Yung-Ruei Chang, HighEfficiency Power Conversion System for Kilowatt-Level Stand-Alone Generation Unit with Low Input Voltage Member, IEEE, 10.1109/TIE.2008.921251.

[41] Shih-Kuen Changchien, Tsorng-Juu Liang, Jiann-Fuh Chen, and Lung-Sheng Yang, Novel High Step-Up DC-DC Converter for Fuel Cell Energy Conversion System 10.1109/TIE.2009.2026364.

[42] Bo Yuan, Xu Yang, Xiangjun Zeng,Jason Duan, Jerry Zhai, and Donghao Li, Analysis and Design of a High Step-up Current-Fed Multiresonant DC-DC Converter With Low Circulating Energy and Zero-Current Switching for All Active Switches 10.1109/TIE.2011.2158036. 
[43] Rong-Jong Wai, Senior Member, IEEE, Li-Wei Liu, and Rou-Yong Duan, High-Efficiency VoltageClamped DC-DC Converter with Reduced Reverse-Recovery Current and Switch-Voltage Stress, 10.1109/TIE.2005.862251.

[44] Subhendu Dutta and Kishore Chatterjee, A Buck and Boost Based Grid Connected PV Inverter Maximizing Power Yield from Two PV Arrays in Mismatched Environmental Conditions 0278-0046 (C) 2017 IEEE.

[45] Ahmad Dehghanzadeha,*, Gholamreza Farahania, Hani Vahedic, Kamal Al-Haddadb, Model predictive control design for DC-DC converters applied to a photovoltaic system, https://doi.org/10.1016/j.ijepes.2018.05.004 